\title{
Stingless bee foraging behavior and pollen resource use in oil palm and rubber plantations in Sumatra
}

\author{
Perilaku mencari polen pada lebah tanpa sengat dan sumber polen di \\ perkebunan kelapa sawit dan karet di Sumatra
}

\author{
Rosi Fitri Ramadani', Rika Raffiudin ${ }^{1}$, Nunik Sri Ariyanti ${ }^{1}$, Siria Biagioni ${ }^{2,3}$, \\ Erin Treanore ${ }^{4}$, Hermann Behling ${ }^{2}$ \\ ${ }^{1}$ Departemen Biologi, Fakultas Matematika dan Ilmu Pengetahuan Alam, IPB University \\ Jalan Meranti, Kampus IPB Dramaga, Bogor 16680, Indonesia \\ ${ }^{2}$ Department of Palynology and Climate Dynamics, Georg-August University of Goettingen \\ Wilhelmsplatz 1, Göttingen 37073, Germany \\ ${ }^{3}$ Quality Services International GmbH \\ Flughafendamm 9a, 28199 Bremen, Germany \\ ${ }^{4}$ Department of Entomology, Pennsylvania State University \\ 501 ASI Building, University Park, PA 16802, United States
}

(diterima Maret 2020, disetujui Maret 2021)

\begin{abstract}
Land transformation in the tropical rainforests to monoculture plantations leads to biodiversity loss and abiotic change. In the oil palm and rubber plantations of Sumatra, we explored the foraging behavior of stingless bees Lepidotrigona terminata, Sundatrigona moorei, and Tetragonula drescheri. Pollen was collected from bees returning to the nest to investigate the floral resources collected by bees inside and outside research plots from both types of plantations. Foraging behavior in both plantations showed an increase in the number of individuals returning to the nest with pollen as the morning progressed, followed by a gradual decrease in the afternoon. The foraging behavior of each stingless bee species was influenced by different environmental factors. While the activity of $S$. moore $i$ was positively correlated with humidity, the activity of $L$. terminate was negatively correlated with temperature. We found that a single pollen load was dominated by a single plant taxon in all bee species in both plantations. All pollen collected in the rubber plantation was from Hevea brasiliensis, suggests that rubber is a potential pollen resource. However, in the oil palm plantation, Asteraceae pollen was the dominant taxon collected by both L. terminata and S. moorei. The comparison to the plant inventories in the plots suggests that almost half of the pollen collected by these two species in the oil palm hives was from outside the plantations, probably in forested patches and surrounding gardens. Finally, based on multivariate analyses, we found no competition for these floral resources between L. terminata and $S$. moorei.
\end{abstract}

Key word: Asteraceae, bee pollen, land transformation, Lepidotrigona terminata, Sundatrigona moorei

\begin{abstract}
ABSTRAK
Alih fungsi lahan dari hutan hujan tropis menjadi perkebunan monokultur menyebabkan hilangnya keanekaragaman hayati, serta berubahnya kondisi abiotik. Penelitian ini mengeksplorasi perilaku tiga spesies lebah tanpa sengat yang ditempatkan di perkebunan kelapa sawit dan perkebunan karet. Polen dari tungkai lebah dikoleksi untuk mempelajari sumber daya yang
\end{abstract}

\footnotetext{
*Penulis korespondensi: Rika Raffiudin. Department of Biology Faculty of Mathematics and Natural Sciences, IPB University
} Jalan Meranti, Kampus IPB Dramaga, Bogor 16680, Indonesia, Tel/Faks:+62-251-8622833, Email: rika.raffiudin@apps.ipb.ac.id 


\begin{abstract}
ditemukan di perkebunan dapat mendukung kebutuhan koloni. Perilaku mencari polen lebah tanpa sengat memperlihatkan peningkatan lebah kembali ke dalam sarang pada pagi hari dan secara perlahan berkurang pada sore hari di kedua perkebunan. Setiap spesies lebah dipengaruhi oleh faktor lingkungan yang berbeda; misalnya aktivitas Sundatrigona moorei Schwarz berkorelasi positif dengan kelembapan dan Lepidotrigona terminata Smith berkorelasi negatif dengan suhu udara. Hasil analisis polen lebah memperlihatkan bahwa dalam satu kantung polen terdapat hanya satu taxa polen yang mendominasi. Semua polen yang dari kantung polen di tungkai lebah dikoleksi di perkebunan karet adalah polen Hevea brasiliensis sehingga mengindikasikan bahwa perkebunan karet dapat menjadi sumber polen jika saat itu berbunga. Hal yang berbeda terjadi di perkebunan sawit, L. terminata dan S. moorei paling banyak mengkoleksi polen Asteraceae dan hampir setengah jumlah spesies polen berasal dari daerah hutan dan kebun-kebun rumah di sekitar perkebunan sawit.
\end{abstract}

Kata kunci: alih fungsi lahan, Asteraceae, Lepidotrigona terminata, polen lebah, Sundatrigona moorei

\section{INTRODUCTION}

The lowland tropical rainforests of Sumatra, Indonesia, are regarded as highly diverse ecosystems supporting a wide variety of species and providing numerous ecosystem functions (Dislich et al. 2017). However, the land transformation of rainforests to agriculture since the 1970 s has resulted in highly-fragmented landscapes (Drescher et al. 2016). The effects of such changes in land use include loss of ecosystem services and functions essential for human livelihoods (Clough et al. 2016; Dislich et al. 2017; Drescher et al. 2016). In the lowlands of the province of Jambi, two of the most common crops are oil palm (Elaeis guineensis) and rubber (Hevea brasiliensis) as monocultures. Among the different ecological functions that might be impacted due to land-use change, pollination is the least studied and understood so far (Dislich et al. 2017). The decline of pollinators is associated with these landscape modifications (Kovács-Hostyánszki et al. 2017).

The stingless bees (Hymenoptera: Apidae, Meliponini) are eusocial corbiculate bees, made up of more than 500 species that are found primarily in tropical and subtropical regions. All stingless bee species lack the ability to sting but they still have a vestigial and non-functional sting (Michener 2007).

Like other bee species, the stingless bees rely on pollen and nectar for their primary source of nutrients, and their foraging behavior usually consists of pollen collection in the morning and nectar during the day (Sommeijer et al. 1983); thus, these activities support flower pollination. Stingless bees as social insects use collective foraging behavior thus increasing the efficiency in the nectar and pollen collection (Biesmeijer \& Slaa 2004). The stingless bee Tetragonula iridipennis Smith foraged for pollen in the morning until noon (8 a.m.-12 p.m.) in Tamil, India (409 $\mathrm{m}$ asl), while the activity of resin collection was from 8 a.m.- 11 a.m. (Vijayan et al. 2018). Similar patterns were also observed in T. laeviceps Smith in Lembang, Indonesia (1,400 $\mathrm{m}$ asl) (Putra et al. 2017). The returning bees collecting pollen were recorded at 9 a.m. and peaking at 12 p.m., and gradually decreased in the number of bees collecting pollen during afternoon.

In this study, we investigated the foraging behavior of three stingless bee species (Lepidotrigona terminata Smith, Sundatrigona moorei Schwarz, and Tetragonula drescheri Schwarz). Studies have shown that environmental factors such as temperature, humidity, rainfall, barometric pressure, and light intensity affect the foraging behavior of stingless bee species (e.g. Heard \& Hendrikz 1993; Contrera et al. 2004). To understand if the different micro-environmental conditions in the different land-use systems can affect stingless bee species behavior, we compared the observed foraging behaviors with recorded temperature, humidity, and light intensity. We also examined the pollen collected by stingless bees in oil palm and rubber plantations to understand how oil palm and rubber plantations can support these three stingless bee species because pollen availability is a major factor affecting the development of bee colonies (Keller et al. 2005). 


\section{MATERIAL AND METHODS}

\section{Selected stingless bee species and study design}

Four stingless bee colonies were collected from the secondary forest of the Harapan rainforest and the Bungku village adjacent to the Harapan Ecosystem Restoration rainforest in the Province of Jambi in Sumatra (Figure 1). The bee colonies were kept in wooden boxes (size $38 \mathrm{~cm}$ x $20 \mathrm{~cm}$ x $15 \mathrm{~cm}$ ). The stingless bee species were identified and deposited at the Entomology Laboratory, Zoology Division, Research Centre for Biology, Indonesian Institute of Sciences. The identification was carried out using morphological characteristics (Sakagami et al. 1990). The four colonies were split among the three species as follows: L. terminata (two colonies), S. moorei, and T. drescheri (Figure 2). L. terminata and T. drescheri were both found in the Harapan rainforest. S. moorei was collected from bamboo internodes in the Bungku village, where it had been placed for a year before collection.

Between August 2014 and March 2015, the wooden boxes containing the colonies were placed in an oil palm and a rubber plantation in two of the plots of the German-Indonesian project EFForTS-CRC990 (Drescher et al. 2016);
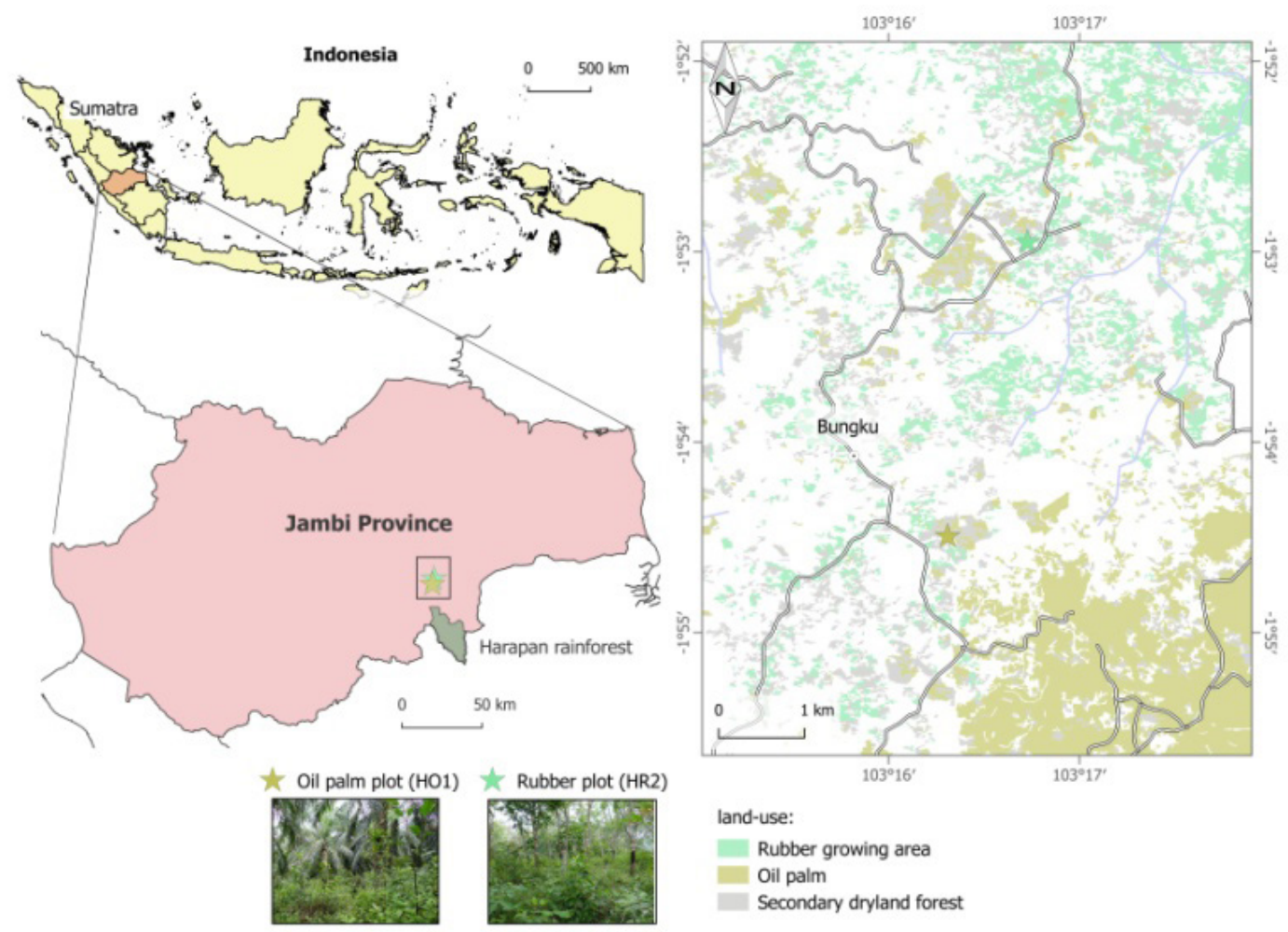

Figure 1. Map of the study location and the oil palm and rubber plot. Land-use data are from 2013 (Melati et al. 2015). Road and river data were digitalized from Bakosurtanal, Peta Rupa Bumi Indonesia scale 1:50.000 in 2013.
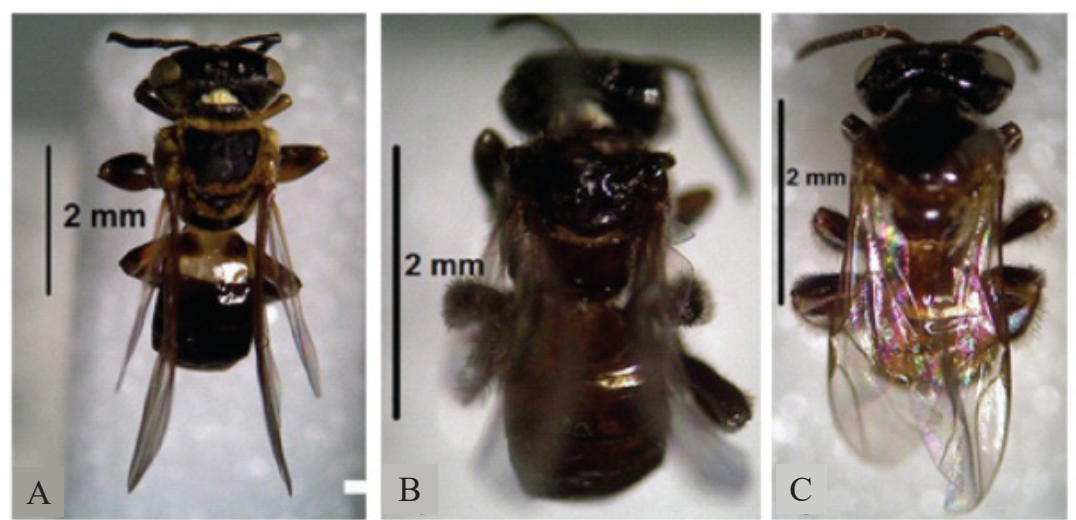

Figure 2. Stingless bees. A: Lepidotrigona terminata; B: Sundatrigona moorei; and C: Tetragonula drescheri . 
$50 \mathrm{~m} \times 50 \mathrm{~m}$ plots codes are HO1 and HR2. One colony each of L. terminata and S. moorei was placed in the oil palm plot (HO1) while the second colony of L. terminata and the colony of T. drescheri was placed in the rubber plot (HR2).

\section{Observation of foraging behavior}

Observational recordings were started when the bees showed acclimatization to the new habitats, and their collection of pollen and resin had stabilized, which occurred after ca. eight days. Bee behavior observations were carried out from 6 a.m. to 12 a.m. and from 2 p.m. to 6 p.m. over ten days for each land-use. We counted the number of bees returned to the nest with and without pollen and resin for ten minutes, with ten minutes intervals using counters. Environmental variables were measured every hour. Temperature and humidity were recorded using a thermo-hygrometer and light intensity was measured using a light meter (Nugroho \& Soesilohadi 2015).

\section{Pollen collection, treatment, and analysis}

To assess individual within-foraging trip resource use and preferences, returning pollen foragers were captured before entering the nests and their pollen loads were collected (Rismayanti et al. 2015). Pollen samples were prepared using the standard Erdtman acetolysis method at the Palynological Laboratory of the University of Jambi, Sumatra, Indonesia (Erdtman 1972). Slides of the pollen samples were then moved to the Department of Palynology and Climate Dynamics at the University of Goettingen in Germany. The pollen grains were photographed, measured, and identified to the lowest taxonomic level possible, using the pollen reference collection available at the department. Where present, the pollen grains were counted up to at least 200 for a total of 57 samples. The pollen taxon with the most abundant count was considered the main pollen source (Louveaux et al. 1978).

\section{Statistical analyses}

We used independent t-test analyses to compare foraging behavior between colonies of different species in the same land-use and between the same species ( $L$. terminata) in the different land-use systems. The dependent variables examined were the number of individuals with pollen and resin. A Generalized Linear Model (GLM) was used for analyzing the effect of environmental factors and foraging behavior of stingless bee (Table 1). All of the above statistical analyses were performed with the software R (cran.r-project.org).

Pollen percentages were calculated from the total sum of pollen grains per captured individual and represented in a pollen diagram using the software C2 (Juggins 2003). The pollen taxa were grouped in local (within plot pollen) and extra-local (outside plot pollen) resources according to the plant inventories of the $50 \mathrm{~m} \times 50 \mathrm{~m}$ plots provided by the EFForTS project (Rembold et al. 2017). To highlight if the plantations are providing enough pollen resources for the bee species, the number of bee individuals, which carried extra-local pollen, was calculated with the total individuals per bee species. The difference in pollen resources used for the different species and the different plantations was visualized using a multivariate unconstrained ordination (PCA). The pollen data used were the Hellinger-transformed percentage of the total pollen sum per bee individual. The PCA was derived using the software CANOCO 5 (TerBraak \& Smilauer 2002).

\section{RESULTS}

\section{Foraging behavior of stingless bee in oil palm and rubber plantation}

Both species, L. terminata, and S. moorei were placed in the oil palm plantation and showed a similar foraging pattern for the observation time (Figure 3). The number of individuals that returned to the nest with pollen and resin increased as the morning progressed and then gradually decreased in the afternoon. The temporal foraging patterns were not statistically different $(\mathrm{P}$-value $=0.051)$.

On the other hand, the two colonies of $L$. terminata and $T$. drescheri, placed in the rubber plantation, showed different temporal foraging patterns. L. terminata was very active in collecting pollen and resin, starting early in the morning and peaking in the early afternoon before gradually decreasing (Figure 4a). Only a small number of $T$. drescheri brought pollen and resin back to the nest during the period of observation (Figure $4 b$ ). 
When comparing the temporal foraging behaviors of the colonies of L. terminata in the different land-use systems, a similar pattern was observed for pollen and resin collections. In both systems, $L$. terminata collection started in the morning, increased through the day until the afternoon, when it started to decrease (Figure 5; P-value $=0.69$ ).

\section{Comparison between foraging behavior and environmental factors}

Our GLM showed a correlation between bee collection of pollen and resin and environmental factors (Table 1). In this study, the interval between 12 a.m. and 2 p.m. was not recorded and therefore was excluded from the GLM. The activities of $L$. terminata in the oil palm plantation and T. drescheri in the rubber plantation were mostly influenced

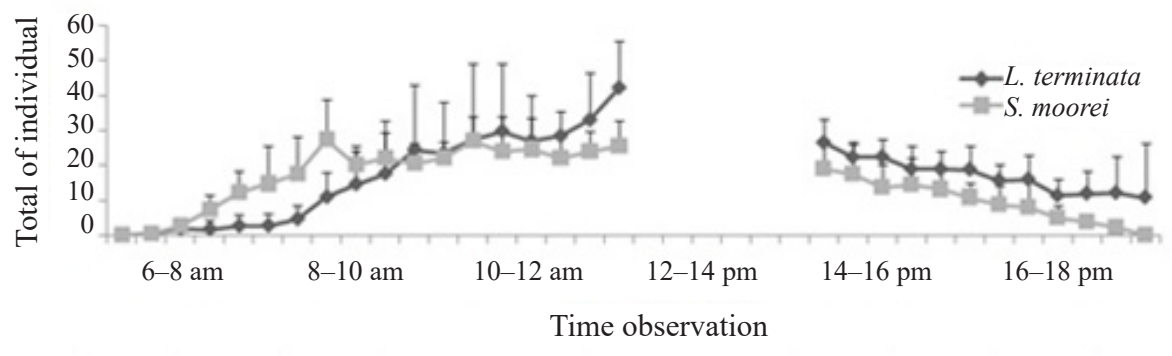

A

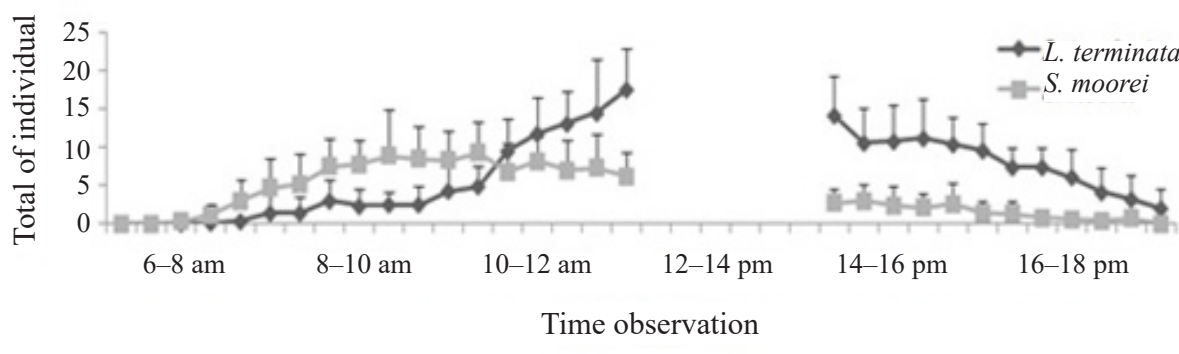

B

Figure 3. Total of the observed individuals of Lepidotrigona terminata and Sundatrigona moorei. A: returning to the nest; B: returning with pollen and resin in oil palm plantations.

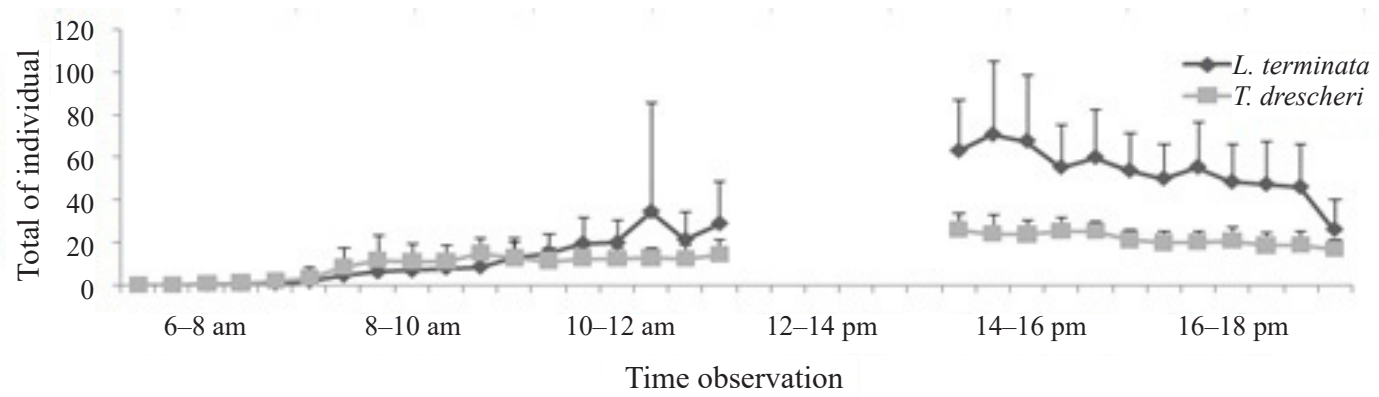

A

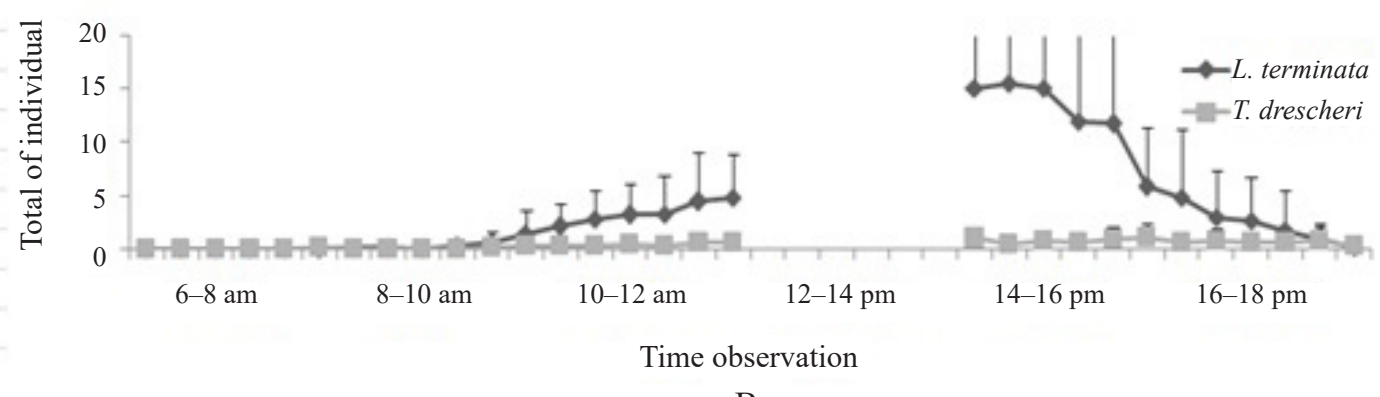

B

Figure 4. Total number of observed individuals of Lepidotrigona terminata and Tetragonula drescheri. a: returning to the nest; b: returning with pollen and resin in the rubber plantation. 
by light intensity and humidity. Both colonies activities were negatively correlated with humidity, while light intensity was positively correlated with the activity $L$. terminata and negatively correlated with the activity of $T$. drescheri.

Humidity and temperature were the factors that most influenced the activity of $L$. terminata in the rubber plantation. Humidity and temperature were negatively correlated with the activity of $L$. terminata.

The activities of $S$. moorei were influenced by all of the environmental factors, i.e., temperature, humidity, light intensity. All the environmental factors positively correlated with the activity of the bees (Table 1).

\section{Results of pollen analyses}

A total of 57 individuals were captured and pollen was collected from their corbiculae in the hind tibia to determine the resource collected by the individual bees. Of those, 15 individuals of $L$. terminata were captured on their flight back to the oil palm plantation nest. All the individual loads were dominated by one single pollen taxon (Figure 6a). The pollen grains from the Asteraceae family were the most frequently targeted ( 7 individuals), followed by Dillenia (5 individuals) and Gluta type (3 individuals).

In the same oil palm plantations, 21 individuals of $S$. moori were captured, and the pollen load was analyzed. Similar to L. terminata, foragers from $S$. moorei also targeted one plant taxon per foraging bout. In order of importance, foraged taxa were Asteraceae, Gluta type and Solanum (4 individuals each), Capparis, Macaranga and Wrightia (2 individuals each), $H$. brasiliensis, Melastoma malabathricum type, and Pinanga type (1 individual each) (Figure 6a, 6b).

In the rubber plantation, 13 individuals of L. terminata were captured. All carried pollen exclusively from rubber $(H$. brasiliensis; Figure 6b). Unfortunately, no pollen data were obtained from the analysis of the pollen load from the eight individuals of $T$. drescheri captured in the same rubber plantation because following preservation and processing, samples no longer contained identifiable pollen.

In the oil palm plantations, both bee species (L. terminata and S. moorei) collected pollen from plants located outside the plot. About half of the individuals of L. terminata carried pollen from outside of the plot (53\%), while $38 \%$ of the $S$. moorei individuals collected pollen from outside of the plot. As L. terminata in the rubber plantation carried pollen exclusively from rubber (H. brasiliensis), all pollen resources were within the plot (Figure 7).

The results of the unconstrained ordinations showed that most of the variability in pollen resources is summarized in the first two PCA axes

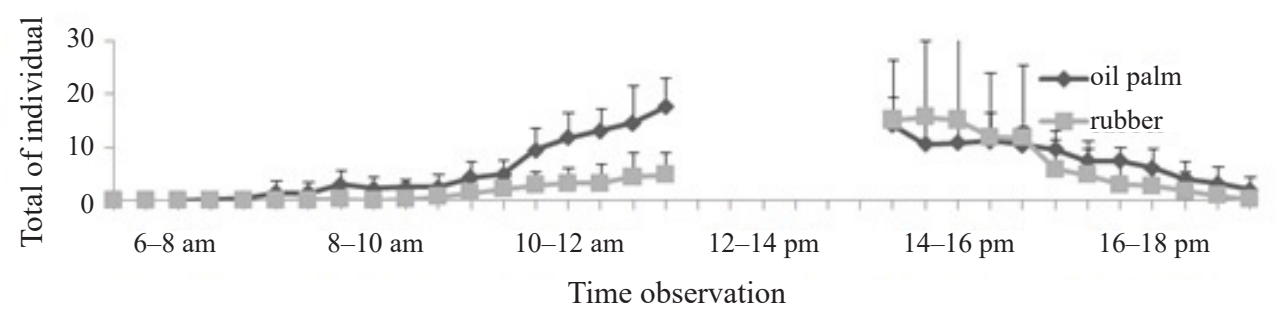

Figure 5. Total individuals of Lepidotrigona terminata that brought back pollen and resin in oil palm and rubber plantations.

Table 1. Results of GLM analysis between stingless bees brought back pollen and resin and environmental factors

\begin{tabular}{lcccccc}
\hline \multirow{2}{*}{ Species } & \multicolumn{2}{c}{ Temperature } & \multicolumn{2}{c}{ Humidity } & \multicolumn{2}{c}{ Light intensity } \\
\cline { 2 - 7 } & Estimates & P-value & Estimates & P-value & Estimates & P-value \\
\hline L. terminata oil palm & $-9.860 \mathrm{e}-02$ & 0.794423 & $-4.473 \mathrm{e}-01$ & $0.000122 * * *$ & $3.074 \mathrm{e}-04$ & $7.05 \mathrm{e}-07 * * *$ \\
S. moorei oil palm & $1.758 \mathrm{e}+00$ & $0.001834 * *$ & $6.050 \mathrm{e}-01$ & $0.000122 * * *$ & $3.446 \mathrm{e}-04$ & $1.24 \mathrm{e}-05 * * *$ \\
L. terminata rubber & $-3.453 \mathrm{e}+00$ & $0.03607 *$ & $-1.053 \mathrm{e}+00$ & $0.00256 * *$ & $1.343 \mathrm{e}-04$ & 0.22518 \\
T. drescheri rubber & $-1.276 \mathrm{e}-01$ & 0.3657 & $-7.161 \mathrm{e}-02$ & $0.0167 *$ & $-2.087 \mathrm{e}-05$ & $0.0389 *$ \\
\hline
\end{tabular}

*: sig $0.05 ; * *$ : sig $0.01 ; * * *$ sig 0.001 

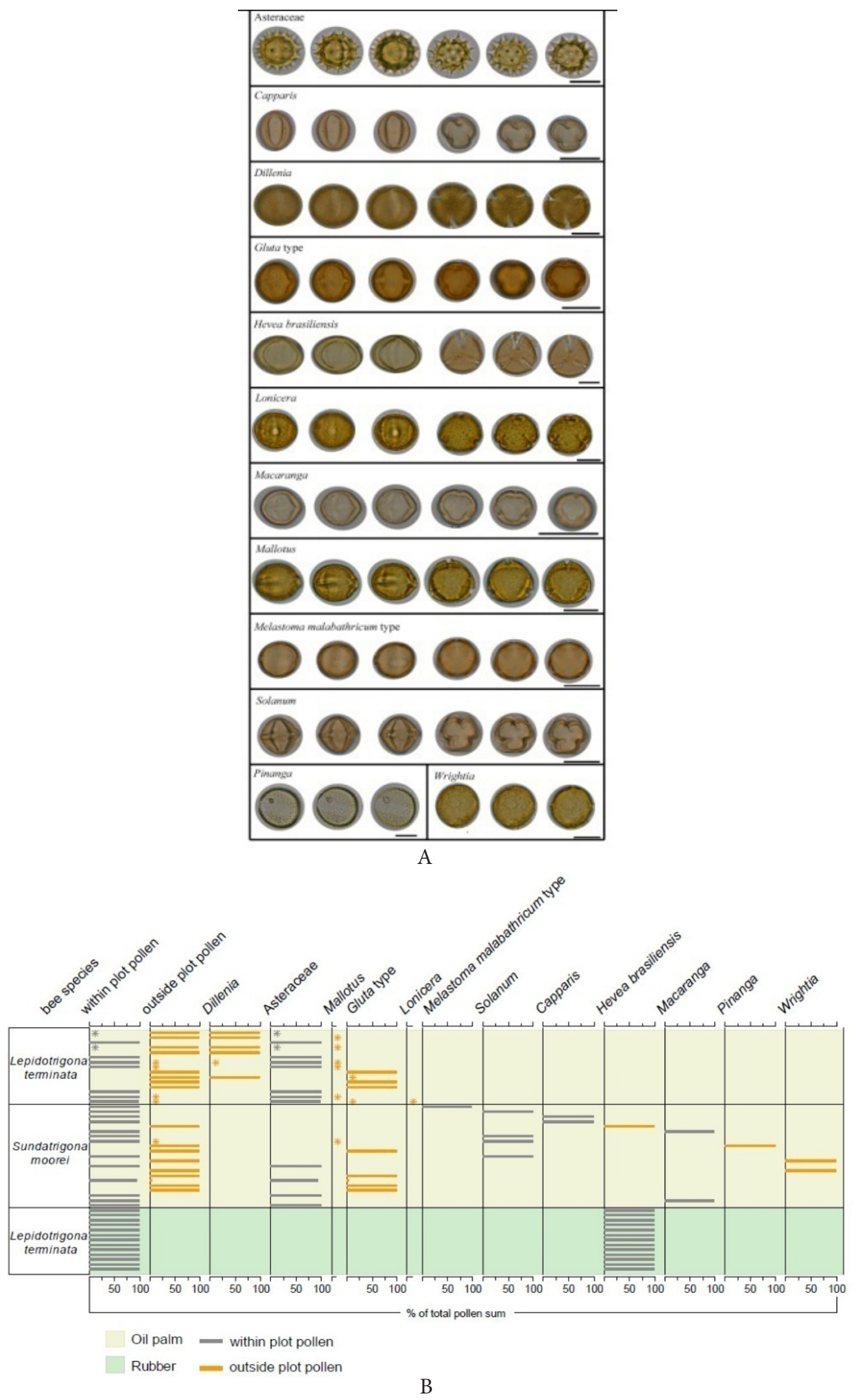

Figure 6. A: Plate of the pollen taxa found in the pollen load of the selected bee species (Black bars below each pollen taxon represent $25 \mu \mathrm{m}$ ); B: Pollen diagram of the pollen resources collected by individuals of Lepidotrigona terminata and Sundatrigona moorei in oil palm and rubber plantation (represented as \% of the total pollen sum). The star symbol denoted values that are below $1 \%$. Grey bars represent pollen from plants recorded in the $50 \mathrm{~m} \times 50 \mathrm{~m}$ plots, the orange the ones that were not recorded inside the plots. 


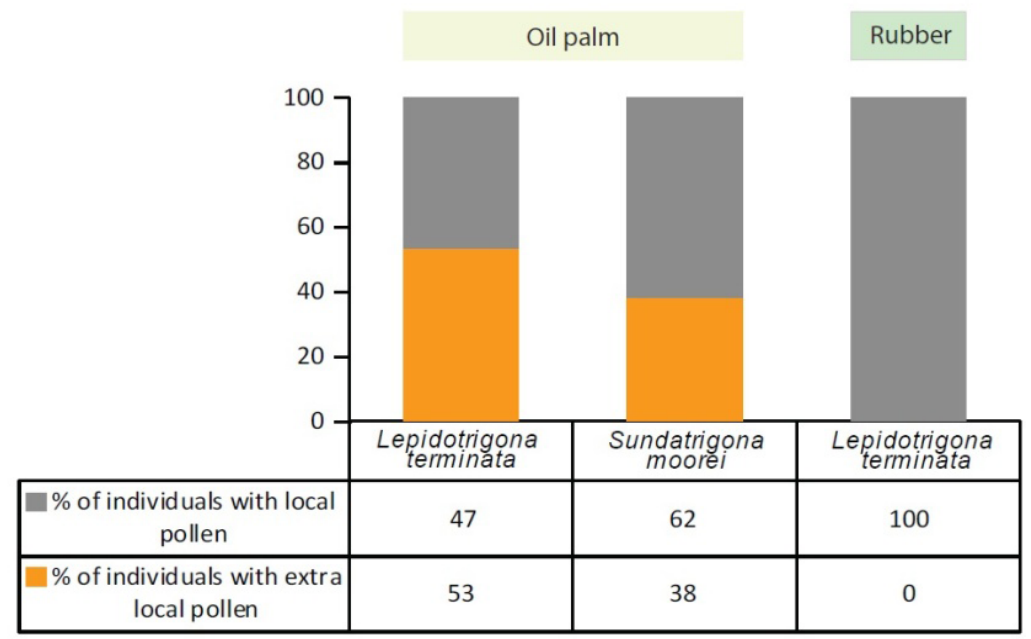

Figure 7. Relative proportions (\%) of the bees carrying pollen from plant species outside and inside the oil palm and rubber plantation plots.

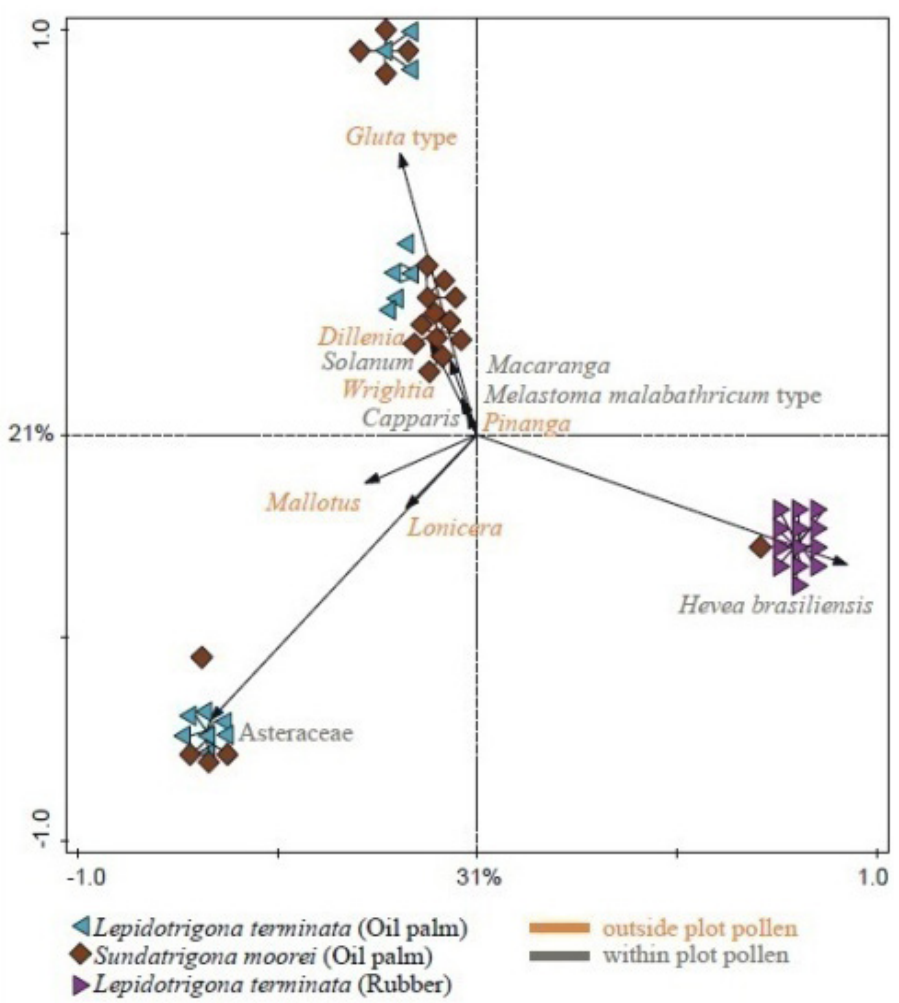

Figure 8. PCA of the pollen loads from Lepidotrigona terminata and Sundatrigona moorei in oil palm and rubber plantations. Data used are the Hellinger transformed \% pollen values carried by each captured bee individual.

$(52 \%)$. The main difference along the first axis is represented by the two plantations (exception for one oil palm bee, individuals scored negatively while all individuals in rubber scored positively on the first axis). As for bee individuals in the oil palm plantations, there was no clear separation between pollen collected outside or within the plot. Both species collected similar resources (Figure 8).

\section{DISCUSSION}

\section{Environmental factors affect foraging behavior of stingless bees differently}

The colonies of L. terminata and $S$. moorei placed in the oil palm plantation showed a similar pattern in their foraging behavior. Their activity for collecting pollen and resin was similar, peaking in 
the middle of the day and then decreasing in the afternoon. However, the colonies of $L$. terminata and $T$. drescheri in the rubber plantation showed different foraging behaviors. Only a few individual T. drescheri brought back pollen and resin.

Our GLM showed that different factors influenced activity in each of the stingless bee species differently. Several previous studies showed that stingless bee activities were positively correlated with humidity and negatively correlated with temperature (Contrera et al. 2004). In this study, the activity of $S$. moorei was positively correlated with humidity, and of L. terminata was negatively correlated with temperature. This result might be related to the dark color of the species. Dark color in stingless bees has been shown to be advantageous to living in wet areas (Pereboom \& Biesmeijer 2003), but such an attribute may also cause individuals to become quickly dehydrated when flying at high temperature.

\section{Resources availability}

The availability of pollen, resin, and nectar resources in the ecosystem was a major factor affecting foraging behavior in the stingless bees we examined (Pierrot \& Schlindwein 2003). When land-use changes from natural native rainforests to monoculture plantations (i.e. oil palm and rubber), both the abundance and diversity of resources may decrease and some bee species may be negatively affected if they are unable to adapt to the new system (Brosi 2009).

Our examination of pollen collection in these three stingless bee species indicates that foragers primarily collect from one plant taxon per foraging bout (Figure 6). This pattern may be due to the social recruitment mechanisms used for foraging in stingless bees, such as the use of trail pheromones (Jarau et al. 2010) and the fact that stingless bees are limited by the amount of pollen they can carry in their corbicula at a time.

However, our results also demonstrated that not all individuals in the same colony focused on the same resource. The range of pollen collection of the two colonies of L. terminata and S. moorei in oil palm plantations was different at the time of capture. Using the plant inventory available from the $50 \mathrm{~m} \times 50 \mathrm{~m}$ plots where the colonies were located (Rembold et al. 2017), we could assess the relative abundance of individuals that collected inside the plot, and the individuals that foraged outside of the plot (Figure 7). It is interesting to note that a large proportion of the individuals from L. terminata collected pollen from plants that were not growing inside the oil palm plot (53\%). Of those plants collected outside, notably, there was pollen from Dillenia and Gluta (Figure 6b). Both of these plant taxa include species that are woody pioneer species growing in secondary or disturbed forests. Their presence in the pollen load indicates that many L. terminata moved outside the oil palm plantations towards more forested patches to collect pollen resources. Similar to $L$. terminata, S. moorei also foraged outside (38\% of the individuals), collecting pollen from plants such as Gluta, Wrightia, rubber (H. brasiliensis), and Pinanga palm (Figure 6b). The fact that the stingless bee did not collect pollen from the oil palm might be related to the oil palm not flowering at the time of observation in the plantation. However, many other oil palm plantations are present outside the plot (Figure 1) and the results indicate that these oil palm resources were ignored and not collected. Replicating this aspect of the study would be beneficial to better understand if oil palm pollen is used as a resource by stingless bees.

The PCA analyses for the two species placed in the oil palm plantation plot revealed that although differences in the pollen resources are noticeable for the different individuals, there is no marked separation between the two species in terms of the pollen collected (Figure 8). This result suggests that the two species did not compete over resources but both colonies moved outside the plantation taking advantage of forested patches and gardens in the surrounding areas.

While in the oil palm plantation, both $L$. terminata and $S$. moorei were simultaneously collecting from three or more different taxa (Figure 6b), however, in the rubber plantation, L. terminata focused exclusively on pollen from $H$. brasiliensis at the time of capture. This suggests that for this species, rubber plantations can support foraging behavior. This could be possibly connected to the anthesis time of $H$. braziliensis flowers, which has been reported to occur between 11.30 a.m. and 01.30 p.m. (Attanayake \& Dharmaratna 1984), 
occurring at the same time as the bees foraging flights. Thus, rubber trees might be well-suited for certain bee species such as L. terminata. Other studies in Thailand found a similar result for species of Apis cerana, A. mellifera, A. florea, and A. dorsata (Wongsiri et al. 2016).

Unfortunately, no pollen collected for $T$. drescheri in the rubber plantation were preserved after preservation and treatment. One possible explanation is that the pollen collected had a thin exine and thus did not survive acetolysis treatment. For instance, these kinds of pollen grains are produced by plant species such as banana (Musa sp.) and orchids (fam. Orchideaceae), which were found inside the rubber plantation (Rembold et al. 2017). However, besides the lack of pollen preservation, we observed that significantly fewer individuals from $T$. drescheri came back to the nest with pollen loads (Figure 3b). The lack of pollen collection from $T$. drescheri might be due to competition over limited or unsuitable pollen resources. The limitation of pollen and resin resources can result in competition among species (Roubik 1981). Competition starts when a species detects the trail pheromone from another species and rapidly takes over the resources. For example, T. spinipes, has been shown to be able to perceive the trail pheromone $M$. ruvifentris, and outcompete them for resources (Nieh et al. 2004). Other studies showed similar behavior in different bee species (e.g. Mohammed \& Starr 1999; Nieh et al. 2004). Thus, it is possible that T. terminata outcompeted T. drescheri for resources in the rubber plantation. Alternatively, $T$. drescheri may have focused more on the collection of nectar in the period of the study. Stingless bees rarely collect pollen and nectar during the same foraging trip (Leonhardt et al. 2007) and when collecting nectar, stingless bees will place it between their mandibles and then return to the nest without pollen in their corbicula (Sommeijer et al. 1983).

Although a preliminary pilot study, in modified landscapes we were able to observe stingless bee resource collection and foraging provided there were sufficient forest resources surrounding the plantations, particularly when oil palm was not flowering. We found mixed results for rubber plantations, where one species (L. terminata) used the pollen of rubber exclusively, while the other species (T. drescheri) showed the least flexibility in their foraging behavior of all three species observed.

\section{CONCLUSION}

In our study, almost all stingless bees showed the general pattern of foraging behavior in oil palm and rubber plantations, i.e. increasing numbers of returning individuals to the nest with pollen as the morning progressed, then gradually decreasing in the afternoon. This study also revealed that the foraging behavior of each species of stingless bee was influenced by different environmental factors. We found that individual pollen loads from all bee species were dominated by a single pollen taxon in both plantations. Rubber plantations can potentially provide pollen resources for the bees in blooming time. However, in oil palm plantations, almost half of pollen collected by L. terminata and $S$. moorei was from outside the plot, with high pollen diversity ranging from 4-9 plant species.

\section{ACKNOWLEDGEMENTS}

This research was supported by Directorate of General Higher Education of Indonesia (DIKTI) for the master program scholarship and research grant, number $1094 / \mathrm{E} 4.4 / 2013$ for the first author. We are grateful for the administration support and logistics was provided by the DFG Sonderforschungsbereich CRC 990 (EFForTS). We thank the staff at the Palynological Laboratory at the University of Jambi for making the facility available for pollen analysis. We also would like to address our thankfulness to Entomology Laboratory staff, Zoology Division and Research Centre for Biology, Indonesian Institute of Sciences, Cibinong for the assistance in stingless bee identification. We want to express our gratitude to Muhammad Zuhdi who helped to map the research location.

\section{REFERENCES}

Attanayake DPSTG, Dharmaratna SC. 1984. Preliminary observation on flowering, pollen 
germination and fruit-set in Hevea species. Journal of Rubber Research Institute of Sri Lanka 62:41-46.

Biesmeijer JC, Slaa EJ. 2004. Information flow and organization of stingless bee foraging. Apidologie 35:143-157.

Brosi BJ. 2009. The complex responses of socials stingless bees (Apidae: Meliponini) to tropical deforestation. Forest Ecology and Management 258:1830-1837. doi: https://doi.org/10.1016/j. foreco.2009.02.025.

Clough Y, Krishna VV, Corre MD, Darras K, Denmead LH, Meijide A, Moser S, Musshoff O, Steinebach S, Veldkamp E, Allen K, Barnes $A D$, Breidenbach N, Brose U, Buchori D, Daniel R, Finkeldey R, Harahap I, Hertel D, Holtkamp MA, Hörandl E, Irawan B, Jaya INS, Jochum M, Klarner B, Knohl A, Kotowska MM, Krashevska V, Kreft H, Kurniawan S, Leuschner C, Maraun M, Melati DN, Opfermann N, Cruzado CP, Prabowo WE, Rembold K, Rizali A, Rubiana R, Schneider D, Tjitrosoedirdjo SS, Tjoa A, Tscharntke T, Scheu S. 2016. Land-use choices follow profitability at the expense of ecological functions in Indonesian smallholder landscapes. Nature Communications 7:1-12. doi: https://doi. org/10.1038/ncomms 13137 .

Contrera FAL, Fonseca VLI, Nieh JC. 2004. Temporal and climatological influences on flight activity in the stingless bee Trigona hyalinata (Apidae, Meliponini). Revista Tecnologia e Ambiente Criciuma 10:35-43.

Dislich C, Keyel AC, Salecker J, Kisel Y, Meyer KM, Auliya M, Barnes AD, Corre MD, Darras K, Faust H, Hess B, Klasen S, Knohl A, Kreft H, Meijide A, Nurdiansyah F, Otten F, Pe'er G, Steinebach S, Tarigan S, Tölle MH, Tscharntke T, Wiegand K. 2017. A review of the ecosystem functions in oil palm plantations, using forest as a reference system. Biological Reviews 92: 1539-1569.

Drescher J, Rembold K, Allen K, Beckschäfer P, Buchori D, Clough Y, Faust H, Jaya INS, Klarner B, Kleinn C, Knohl A, Kotowska MM, Krashevska V, Krishna V, Leuschner C, Lorenz W, Meijide A, Melati D, Nomura M, Cruzado CP, Qaim M, Siregar IZ, Steinebach S, Tjoa A, Tscharntke T, Wick B, Wiegand K, Kreft H, Scheu S. 2016. Ecological and socio-economic functions across tropical land use systems after rainforest conversion. Philosophical Transaction of the Royal Society 371:1-8. doi: https://doi. org/10.1098/rstb.2015.0275.
Erdtman G. 1972. Pollen Morphology and Plant Taxonomy. New York: Hafner Publishing.

Heard TA, Hendrikz JK. 1993. Factors influencing flight activity of colonies of the stingless bee Trigona carbonaria (Hymenoptera: Apidae). Australian Journal of Zoology 41:343-530. doi: https://doi.org/10.1071/ZO9930343.

Jarau S, Dambacher J, Twele R, Aguilar I, Francke W, Ayasse M. 2010. The trail pheromone of a stingless Bee, Trigona corvina (Hymenoptera, Apidae, Meliponini), varies between populations. Chemical Senses 35:593-601. doi: https://doi. org/10.1093/chemse/bjq057.

Juggins S. 2003. C2-Software for ecological and palaeoecological data analysis and visualisation User guide Version 1.5.

Keller I, Fluri P, Imdorf A. 2005. Pollen nutrition and colony development in honey bees Part II. Bee World 86:27-34. doi: https://doi.org/10.1080/00 05772X.2005.11099650.

Kovács-Hostyánszki A, Espíndola A Vanbergen, AJ, Settele J, Kremen C, Dicks LV. 2017. Ecological intensification to mitigate impacts of conventional intensive land use on pollinators and pollination. Ecology Letter 20:673-689. doi: https://doi.org/10.1111/ele.12762.

Leonhardt SD, Dworschak K, Eltz T, Bluthgen N. 2007. Foraging loads of stingless bees and utilization of stored nectar for pollen harvesting. Apidologie 30:125-135. doi: https://doi. org/10.1051/apido:2006059.

Louveaux J, Maurizio A, Vorwohl G. 1978. Methods of melissopalynology. Bee World 59:139-157. doi: https://doi.org/10.1080/00057 72X.1978.11097714.

Melati DN, Jaya INS, Perez-Cruzado C, Zuhdi M, Fehrmann L, Magdon P, Klein C. 2015. Spatiotemporal analysis on land transformation in a forested tropical landscape in Jambi Province, Sumatera. In: Conference Presentation of European Geoscience Union General Assembly (Vienna, 17 April 2015). Vienna: EGU General Assembly.

Michener CD. 2007. The Bees of the World. London: John Hopkins University Press.

Mohammed F, Starr CK. 1999. Comparative foraging of the sympatric stingless bees Trigona nigra dan Partamona nigrior (Apidae: Meliponini). Proceedings of the Section Experimental and Applied Entomology 10:195-202.

Nieh JC, Barreto LS, Contrera FAL, Foncesa VLI. 2004. Olfactory eavesdropping by a competitively foraging stingless bee, Trigona 
spinipes. Proceeding of the Royal Society of London 271:1633-1640. doi: https://doi. org/10.1098/rspb.2004.2717.

Nugroho RB, Soesilohadi RCH. 2015. Foraging activity of worker stingless bee, Trigona sp. (Hymenoptera: Apidae) in Gunung Kidul. Biomedika 8:37-41.

Pereboom JJM, Biesmeijer JC. 2003. Thermal constraints for stingless bee foragers: the importance of body size and coloration. Oecologia 137:42-50. doi: https://doi.org/10.1007/s00442003-1324-2.

Pierrot LM, Schlindwein C. 2003. Variation in daily flight and foraging patterns in colonies of urucu-Melipona scutellaris Latreille (Apidae, Meliponini). Revista Brasileira de Zoologia 20: 565-571.

Putra RE, Subagio J, Kinasuh I, Permana AD, Rosmiati. 2017. Pola kunjungan serangga liar dan efek penambahan koloni Trigona (Tetragonula) laeviceps Smith pada penyerbukan Kabocha (Cucurbitamaxima). Jurnal Entomologi Indonesia 14:69-79. doi: https://doi.org/10.5994/ jei.14.2.69.

Rembold K, Mangopo H, Tjitrosoedirjo SS, Kreft H. 2017. Plant diversity, forest dependency, and alien plant invasion in tropical agricultural landscapes. Biological Conservation 213:234-242. doi: https://doi.org/10.1016/j.biocon.2017.07.020.

Rismayanti, Triadiati, Raffiudin R. 2015. Ecology service of herbaceous plants for Trigona's bee. Jurnal Sumber Daya Hayati 1:19-25. doi: https://doi.org/10.29244/jsdh.1.1.19-25.
Roubik DW. 1981. Comparative foraging behavior of Apis mellifera and Trigona corvina (Hymenoptera: Apidae) on Baltimora recta (Compositae). Revista de Biologia Tropical 29:177-184.

Sakagami SF, Ohgushi R, Roubik DW. 1990. Natural History of Social Wasps and Bees in Equatorial Sumatra. Sapporo: Hokkaido Univ. Pr.

Sommeijer MJ, De Rooy GA, Punt W, De Bruijn LLM. 1983. A comparative study of foraging behavior and pollen resources of various stingless bees (Hym. Meliponinae) and honeybees (Hym. Apinae) in Trinidad, West-Indies. Apidologie 14:205-224.

TerBraak CJ, Smilauer P. 2002. CANOCO reference manual and Cano Draw for Windows user's guide: software for canonical community ordination (version 4.5). www.canoco.com.

Vijayan M, Saravanan PA, Srinivasan MR. 2018. Effect of season and timings on the foraging behaviour of stingless Bee, Tetragonula iridipennis Smith (Hymenoptera: Apidae). Madras Agricultural Journal 105:286-290.

Wongsiri S, Pyramarm K, Leepitakrat S, Sirinum. 2016. Rubber: a potential major honey plant in Thailand. Bee World 80:187-190. doi: https:// doi.org/10.1080/0005772X.1999.11099454. 